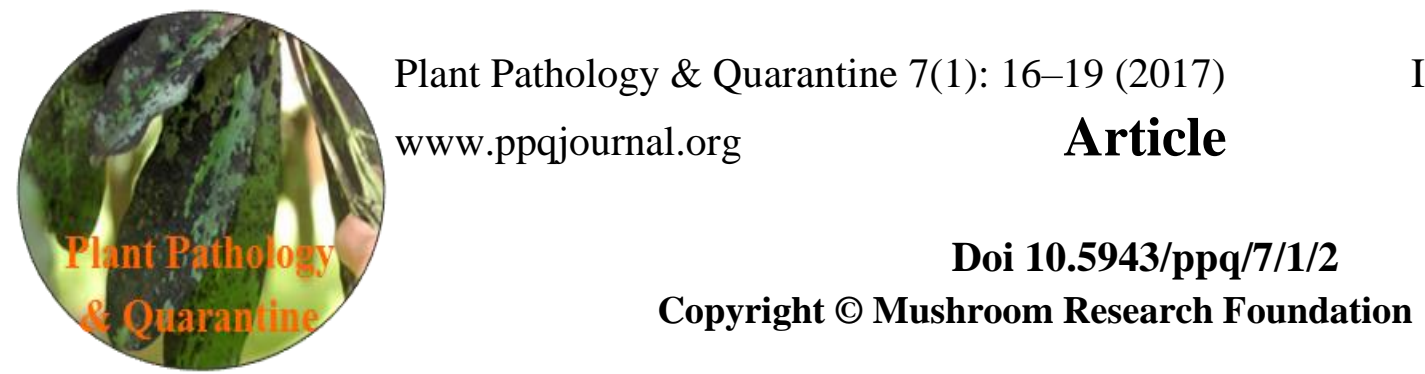

\title{
Additions to the leaf pathogenic fungi of Turkey
}

\author{
Erdoğdu $\mathbf{M}^{1^{*}}$, Suludere $Z^{2}$ and Hüseyin $\mathbf{E}^{1}$ \\ ${ }^{1}$ Ahi Evran University, Arts and Sciences Faculty, Department of Biology, Kırşehir, Turkey \\ ${ }^{2}$ Gazi University, Faculty of Science, Department of Biology, Ankara, Turkey
}

Erdoğdu M, Suludere Z, Hüseyin E 2017 - Additions to the leaf pathogenic fungi of Turkey. Plant Pathology \& Quarantine 7(1), 16-19, Doi 10.5943/ppq/7/1/2

\begin{abstract}
Septoria ornithogali on living leaves of Ornithogalum sp. and Phyllosticta onosmae on living leaves of Onosma tauricum var. tauricum are reported as new to the mycota of Turkey. Distinguishing morphological characters are described and illustrated for each species.
\end{abstract}

Key words - microfungi - Phyllosticta onosmae - Septoria ornithogali

\section{Introduction}

The asexual morph genus Septoria Sacc. includes plant parasitic fungi causing diseases on a great number of cultivated and wild plants. They most frequently attack the leaves, seldom the flowers of plants, evoking the appearance of necrotic spots. These damages affect the vitality and biological productivity of the attacked plants. The Septoria species include economically important plant pathogens, parasitizing on cereals, grasses, vegetables, ornamental plants, medicinal plants, forest trees and shrubs (Bacigálová et al. 2010).

Phyllosticta Pers. is an important coelomycetous plant pathogenic genus known to cause leaf spots and various fruit diseases worldwide on a large range of hosts. Species recognition in Phyllosticta has historically been based on morphology, culture characters and host association. Although there have been several taxonomic revisions and enumerations of species, there is still considerable confusion when identifying taxa (Wikee et al. 2011).

\section{Materials \& Methods}

Plant specimens infected with microfungi were collected from Kaman district in Kurşehir Province of Turkey and prepared according to established herbarium techniques. Host plants were identified using the Flora of Turkey and East Aegean Islands (Davis et al. 1978, 1984). The fungal specimens were examined microscopically by thin sections. Microscopic examination and microphotographs were done using a Leica DM E light microscope. A Leica EZ4D stereo microscope was used for close-up photographs of the pycnidia on the leaf surface. The microfungi were identified using the relevant literature (Saccardo 1884, Byzova et al. 1967, TeterevnikovaBabayan 1987, Vanev et al. 1997). All specimens examined were deposited in the mycological collection of the Department of Biology, Arts and Sciences Faculty, Ahi Evran University, in Kırşehir Province of Turkey.

For scanning electron microscopy (SEM), 8-10 mm-square pieces of infected leaves bearing conidia and/or pycnidia were mounted on the SEM stubs with double-sided adhesive tape. 
They were coated with gold using a Polaron SC 502 Sputter Coater and were examined with a Jeol JSM 6060 scanning electron microscope operated at 5-10 kV in the Electron Microscopy Unit, Faculty of Science, Gazi University (Turkey).

\section{Results}

Septoria ornithogali Pass.

Fig. 1

Spots visible on upper leaf surface, oblong to irregular, 9-13 mm long, ochraceous. Conidiomata pycnidial, epiphyllous, immersed, becoming erumpent, globose, unilocular, 115-138 $\mu \mathrm{m}$ in diameter, brown; ostiole subcircular to irregular, $20-40 \mu \mathrm{m}$ in diameter. Conidia cylindrical, fusiform, attenuate both ends, straight to slightly curved, 40-50 × 2.2-3.5 $\mu \mathrm{m}, 1-3$-septate, usually 3-septate, not constricted, hyaline.

Material examined - Turkey, Kırşehir, Kaman, Tatık village, around Kızdere area, on living leaves of Ornithogalum sp., 26 May 2012, 1059 m alt., M. Erdoğdu 2181.
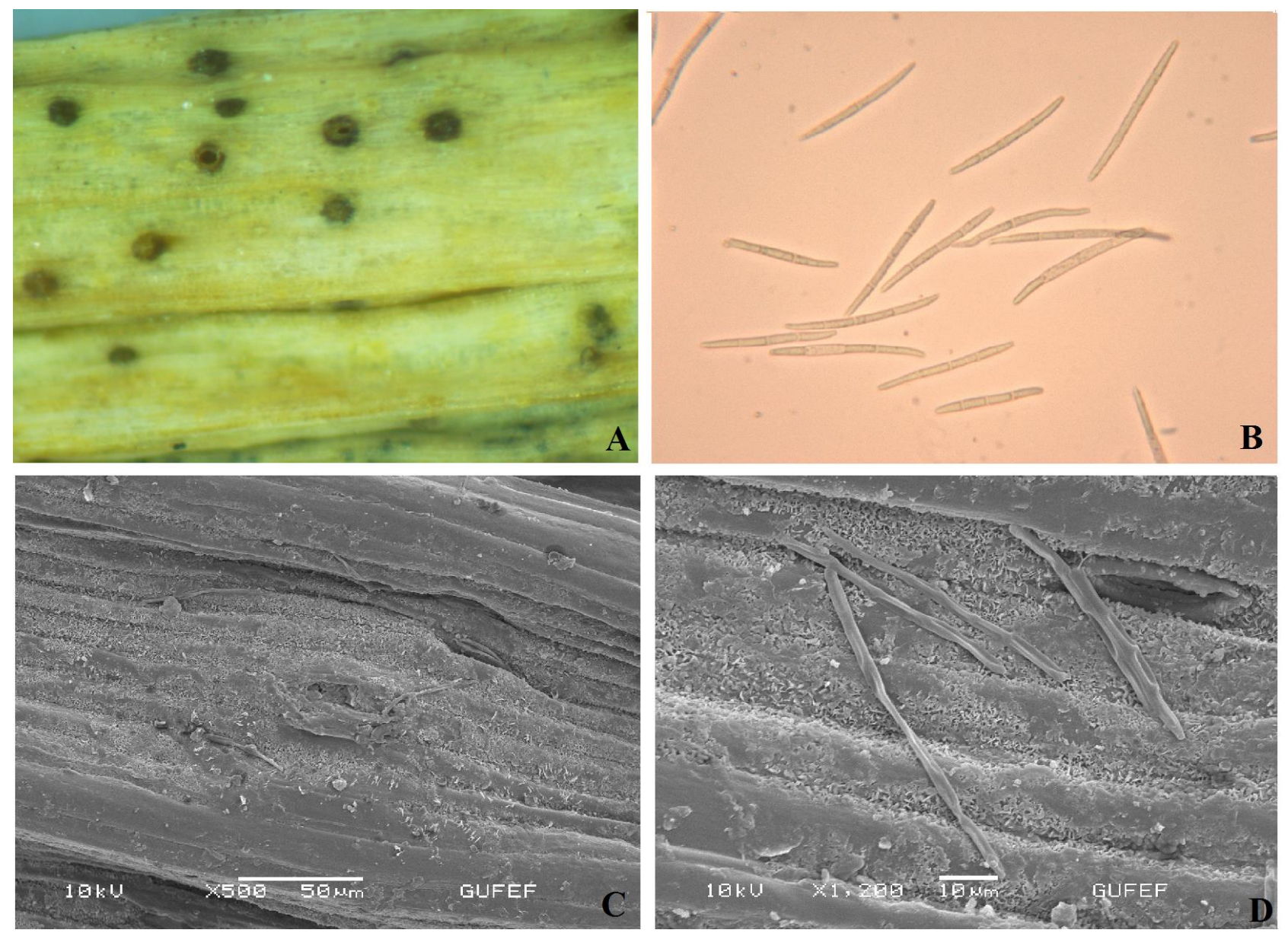

Fig. 1 - Septoria ornithogali. A, General appearance of infected leaf. B, Conidia. C, Pycnidia on leaf (SEM). D, Conidia (SEM).

Phyllosticta onosmae Vasyag

Fig. 2

Spots orbicular or oblong, 1-2 $\mathrm{mm}$ in diameter, white, spot margin brown. Conidiomata pycnidial, epiphyllous, semi-immersed, globose, unilocular, thin-walled, 140-170 $\mu \mathrm{m}$ in diameter, dark brown; ostiole subcircular to irregular, $25-30 \mu \mathrm{m}$ in diameter. Conidia 1-celled, elliptic, oblong, obtuse both ends, 5.5-7 × 2.5-3 $\mu \mathrm{m}$, hyaline.

Material examined - Turkey, Kırşehir, Kaman, Tatık village, around Kızdere area, on living leaves of Onosma tauricum var. tauricum Pallas ex Willd, 27 May 2012, 1070 m alt., M. Erdoğdu 2185. 

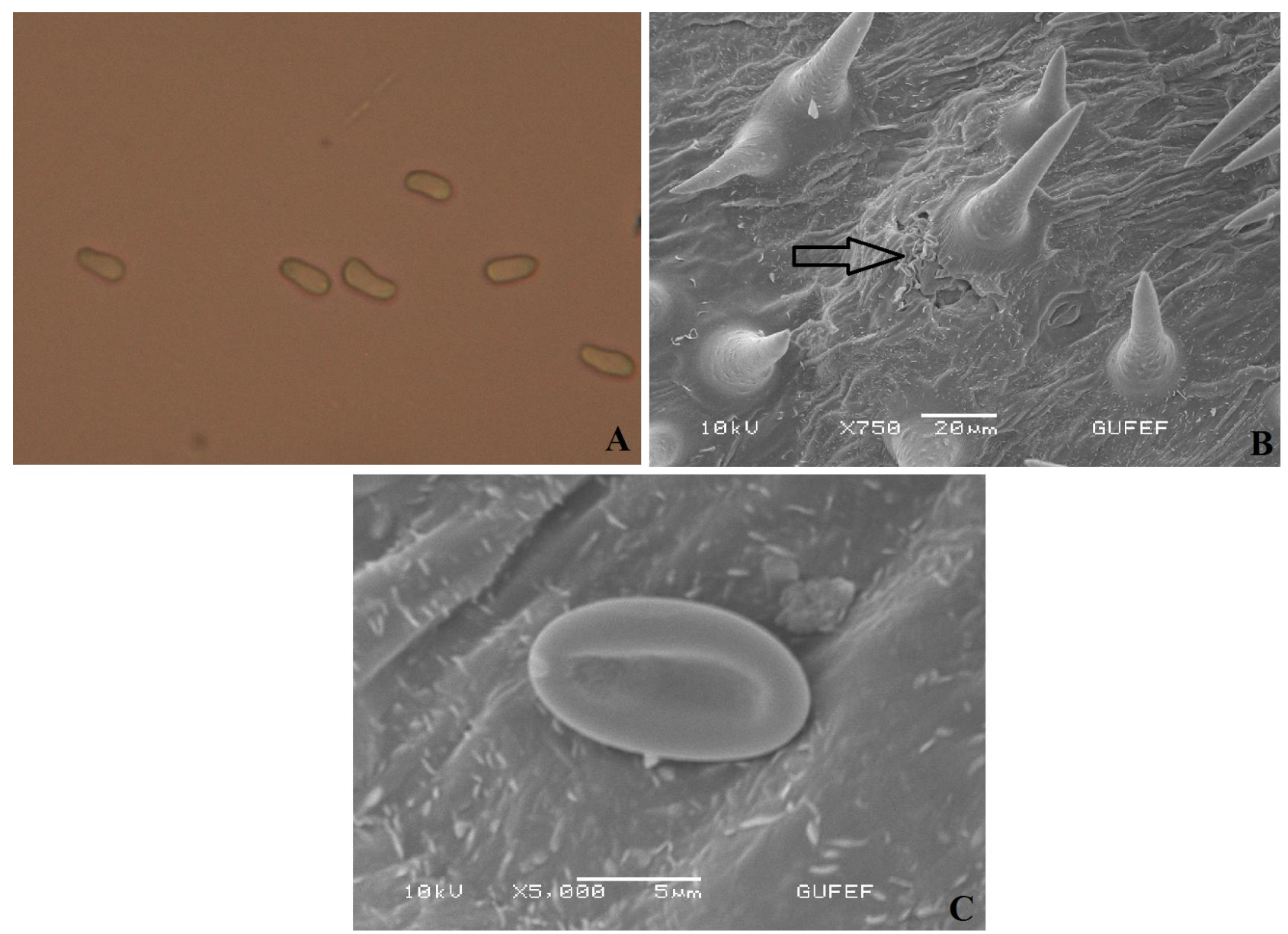

Fig. 2 - Phyllosticta onosmae. A, Conidia. B, Conidia (SEM). C, Conidium (SEM).

\section{Discussion}

The genus Septoria is one of the largest genera of plant pathogens, causing a range of disease symptoms including leaf and fruit spots in many agricultural crops, as well as horticultural and native plants (Holliday 1989). Septoria ornithogalea Sacc., S. ornithogali Pass. and $S$. ornithogalicola Hollós have been recorded on Ornithogalum spp. (Saccardo 1884). Septoria ornithogali infects Ornithogalum comosum L. in Bulgaria (Vanev et al. 1997), O. lacteum Jacq. in Southern Africa (Doidge 1950), O. magnum Krasch. \& Schischk. in Armenia (Simonyan 1981), O. montanum Cirillo in Bulgaria (Vanev et al. 1997), O. nutans L. in Greece (Pantidou 1973), O. platyphyllum Boiss. and O. pyrenaicum L. in Armenia (Simonyan 1981), O. umbellatum L. in Bulgaria (Vanev et al. 1997), USA (Anonymous 1960), Romania (Radulescu et al. 1973). Eightytwo species of Septoria are now known from Turkey (Selçuk et al. 2009, Ekici et al. 2012, Kabaktepe et al. 2013). Septoria ornithogali is reported for the first time from Turkey.

The genus Phyllosticta includes a diversity of pathogenic and endophytic species associated with plants worldwide (van der Aa \& Vanev 2002). Phyllosticta onosmae is the only species of Phyllosticta described on Onosma sp. The morphological characters of our specimens agree with the previous record of this species. Phyllosticta onosmae infects Onosma simplicissimum L. in Kazakhistan (Byzova et al. 1967). Phyllosticta onosmae is new for mycoflora of Turkey.

\section{Acknowledgements}

This work was financed by the Ahi Evran University BAP Coordination (Project no: FBA11-08). 


\section{References}

Aa HA van der, Vanev S. 2002 - Revision of the species described in Phyllosticta. Centraalbureau voor Schimmelcultures, Utrecht.

Anonymous 1960 - Index of plant diseases in the United States. U.S.D.A. Agriculture Handbook $165,1-531$.

Bacigálová K, Turis P, Park M-J, Shin H-D. 2010 - First report of Septoria infection on Cyclamen fatrense. Thaiszia Journal of Botany 20, 109-114.

Byzova ZM, Vasyagina MP, Dejeva NG, Kalymbetov BK, Pisareva NF, Schwarzman SR. 1967 Flora Sporovykh Rastenii Kazakhstana Vol 5(1). Sphaeropsidales, Alma-Ata.

Davis PH, Edmondson JR, Mill RR, Parris BS. 1978 - Onosma L. In: Davis PH, editor. Flora of Turkey and the East Aegean Islands Vol 6. Edinburgh University Press, Edinburgh.

Davis PH, Mill RR, Tan K. 1984 - Ornithogalum L. In: Davis PH, editor. Flora of Turkey and the East Aegean Islands Vol 8. Edinburgh University Press, Edinburgh.

Doidge EM. 1950 - The South African fungi and lichens to the end of 1945. Bothalia 5, 1-1094.

Ekici T, Erdoğdu M, Aytaç Z, Suludere Z. 2012 - Septoria species in Kıbrıs Village Valley (Ankara, Turkey). Nova Hedwigia 95, 483-491.

Holliday PA. 1989 - Dictionary of plant pathology. Cambridge University Press, Cambridge.

Kabaktepe Ş, Mutlu B, Karakuş Ş. 2013 - New records of microfungi from Malatya province in Turkey. Hacettepe Journal of Biology and Chemistry 41(3), 221-224.

Pantidou ME. 1973 - Fungus-host index for Greece. Benaki Phytopathological Institute, Kiphissia, Athens.

Radulescu E, Negru A, Docea E. 1973 - Septoriozele din Romania. Editura Academiei Republicii Socialiste România, Bucuresti.

Saccardo PA. 1884 - Sylloge Fungorum Omnium Hucusque Cognitorum Vol 3. J. W. Edwards, Patavii, Italy.

Selçuk F, Erdoğdu M, Akgül H, Hüseyin E. 2009 - The genus Septoria Sacc. in Turkey. Mycopath 7(1), 21-28.

Simonyan SA. 1981 - Mycoflora of Botanical Gardens and Arboreta in Armenia. Armenian SSR, Hayka.

Teterevnikova-Babayan DN. 1987 - Fungi of the genus Septoria in USSR. Akademiya Nauk Armyanskoi SSR, Erevan.

Vanev SG, Sameva EF, Bakalova GG. 1997 - Fungi Bulgaricae Vol 3(1). Pensoft Publishers, Sofia.

Wikee S, Udayanga D, Crous PW, Chukeatirote E, McKenzie EHC, Bahkali AH, Dai DQ, Hyde KD. 2011 - Phyllosticta - an overview of current status of species recognition. Fungal Diversity 51, 43-61. 